\title{
ГЛАВА V
}

\section{ОПОДАТКУВАННЯ ДОХОДІВ ФІЗИЧНИХ ОСІБ: ПРОБЛЕМИ ТА ПЕРСПЕКТИВИ РОЗВИТКУ}

\section{Теоретична сутність та економічний зміст}

оподаткування доходів фізичних осіб. Оподаткування доходів фізичних осіб $є$ складовою частиною фінансового механізму держави. У результаті перерозподілу доходів (платежів) фізичних осіб, з однієї сторони, реалізується економічна доктрина щодо рівня добробуту різних верств населення, а з іншої- формується фінансова база держави. Податок із доходів фізичних осіб має скерованість на соціальну справедливість податкової систем, оскільки ставить рівень оподаткування в пряму залежність від обсягів доходу платника.

Цей податок є одним із найстабільніших та найдієвіших джерел формуванням дохідної частини бюджету. ПДФО посідає друге місце в податкових надходженнях Зведеного бюджету України після внутрішніх податків на товари і послуги (ПДВ та акцизний податок). Податку на доходи фізичних осіб притаманні як фіскальні, так і регулятивні властивості. 3 фіскальної точки зору цей податок $€$ одним із важливих джерел формування доходів бюджету. База оподаткування і відповідно податкові надходження залежать від циклічності коливань економіки, а також розвитку промислового потенціалу регіонів.

Щодо регулятивного макроекономічного впливу, податок на доходи фізичних осіб $є$ одним із ефективних «вбудованих стабілізаторів» економічного циклу, оскільки притаманна йому база оподаткування порівняно плавно реагує на швидкі економічні підйоми та спади. За своїм фіскальним значенням ще донедавна податок не займав основних позицій, що обумовлювалося 
недосконалістю його фіскального механізму, низьким рівнем доходів більшості громадян та неготовністю платників до сплати податку внаслідок недовіри щодо ефективного використання податків державою.

Соціально-регулююча роль ПДФО полягає в тому, що він ставить рівень оподаткування в пряму залежність від обсягу доходу платників за умови, що в країні використовується прогресивна шкала оподаткування. За допомогою прогресивних ставок i пільг в оподаткуванні можна зменшувати податковий тягар для малозабезпечених верств населення i посилювати для осіб iз високими доходами. Послаблення соціальної функції оподаткування доходів є одним із основних дестабілізуючих факторів вітчизняної податкової системи.

Специфічною складовою механізму оподаткування доходів фізичних осіб у вигляді заробітної плати $є$ податкова соціальна пільга. Її зміст полягає у зменшенні бази оподаткування для осіб із низьким рівнем заробітної плати. Податковим кодексом було передбачене збільшення розміру ПСП до рівня мінімальної заробітної плати з 1 січня 2014 р. Такі зміни мали б зміст, оскільки мінімальна заробітна плата залишалась у розмірі, визначеному урядом і це відігравало роль захисту малозабезпечених верств населення. Однак, розмір податкової соціальної пільги залишався на рівні 50\% від мінімальної заробітної плати і з 1 січня 2016 року цей рівень було встановлено безстроково. У результаті маємо складний та заплутаний механізм надання податкової соціальної пільги щодо використання якої існує багато обмежень. А фактично «ціна питання» становить від 124 грн до 248 грн, на які зменшується сума ПДФО особам, які скористатись правом на ПСП.

У контексті соціального аспекту оподаткування доходів 
фізичних осіб хотілось би зауважити зменшення ставки з 20 до 18\% на пасивні доходи, зокрема відсотки за депозитами (в результаті проведеного декларування доходів нашими урядовцями досить поширеною статтею доходів були саме отримані дивіденди), а також уведене урядом оподаткування пенсій. Податковий тиск на громадян iз низьким рівнем доходів залишається високим, що негативно впливає на їх рівень життя, тоді як більш заможні громадяни сплачують податок із пасивних доходів за заниженими ставками.

Таким чином, на сьогоднішньому етапі податок на доходи фізичних осіб у частині чинних ставок $\epsilon$ надміру фіскальноспрямованим та не виконує належним чином соціальнорегулюючої функції. Відхід від прогресивного оподаткування лише погіршує ситуацію, поглиблюючи диференціацію між доходами різних соціальних груп населення, збільшуючи нерівність між ними.

Податку на доходи фізичних осіб як економічній категорії властиві такі характеристики:

- фінансово-економічна - відчужуються частина отриманого доходу платника на користь держави, органів місцевого самоврядування для виконання ними своїх функцій. Тобто $є$ платою громадянина за послуги держави;

- політична - узгоджуються інтереси різних верств суспільства. Тобто виробляється та реалізовується сукупність норм та принципів щодо визначення ставки податку, об'єкту оподаткування, пільг, які повинні врегулювати суспільні відносини;

- соціальна - зачіпає інтереси економічно активного населення країни, згладжує нерівність у доходах, яка існує між різними соціальними групами (хто заробляє більше - більше платить), впливає на рівень заощаджень населення, обсяг, динаміку і структуру внутрішнього попиту, якість життя, демографічні та 
інші показники соціальної сфери. У разі зменшення ставки податку збільшується попит на товари та послуги, створюються умови для збільшення заощаджень, i, навпаки, у разі збільшення ставки податку платник податку сплачує з свого доходу в бюджет більше залишаючи для власного споживання менше.

Через ПДФО реалізується зв'язок громадян-платників 3 державою (в особі фіскальних органів) i місцевими органами самоврядування, тим самим громадяни стають причетними до формування доходів бюджету і набувають прав для контролю за ефективним використанням державних ресурсів.

У сучасних умовах поряд 3 фіскальною особливу увагу держава повинна приділяти регулюючій функції ПДФО, бо податок чинить серйозний вплив на рівень і структуру доходів населення, його платоспроможний попит.

Значущість ПДФО обумовлена тим, що він:

- безпосередньо зачіпає інтереси всіх без винятку верств економічно активного населення країни;

- один з основних податків, який дозволяє в максимальному ступені реалізувати основні принципи оподаткування: справедливість і рівномірність розподілу податкового тягаря;

- дозволяє змінювати розмір кінцевих доходів населення без зміни відповідності між результатами праці та їі оплатою;

- впливає на структуру кінцевих доходів населення, а отже, i на структуру потреб населення;

- дозволяє обкладати доходи, які отримуються з різних джерел.

Отже, податок на доходи фізичних осіб є одним із основних у податковій системі країни та відіграє значну фіскальну роль. Однак, головною проблемою є те, що система оподаткування доходів у 
нашій країні на сьогодні не є нейтральною і соціально справедливою. Уніфікація ставки податку на рівні 18\% та оподаткування дивідендів за значно нижчою ставкою в 5\% призводить до ситуації, коли бідні верстви населення, для яких основним джерелом доходу є зарплата, у структурі власних витрат сплачують значно більший обсяг коштів, ніж заможні.

Податок на доходи фізичних осіб в Україна відіграє важливу роль у наповненні бюджетів різних рівнів. Однак, детальне дослідження механізму його функціонування виявило низку проблем, що провокують значне соціальне розшарування населення, знижують рівень плато- і податкоспроможності громадян і сприяють формуванню високого рівня тіньових доходів.

Порядок нарахування та сплати податку на доходи фізичних осіб в Україні. Платником ПДФО є фактично - фізична особа - резидент та нерезидент, яка отримує заробітну плату в Україні, з якої і вираховується та сплачується ПДФО, а вираховує податок із заробітної плати та перераховує його бюджету податковий агент - юридична особа (iї філія, відділення, інший відокремлений підрозділ), самозайнята особа, представництво нерезидента - юридичної особи, інвестор (оператор) за угодою про розподіл продукції, які незалежно від організаційно-правового статусу та способу оподаткування іншими податками та/або форми нарахування (виплати, надання) доходу (у грошовій або негрошовій формі) зобов'язані нараховувати, утримувати та сплачувати податок до бюджету від імені та за рахунок фізичної особи 3 доходів, що виплачуються такій особі, вести податковий облік, подавати податкову звітність контролюючим органам та нести відповідальність за порушення норм ПК України [1].

Податок на доходи фізичних осіб сплачують зі своїх доходів 
фізичні особи за ставкою 18\%, окрім спадщини, доходів від продажу рухомого та нерухомого майна, які оподатковуються за нижчими ставками. Розрахувати, утримати й сплатити цей податок iз виплачених доходів повинен роботодавець, який виконує роль податкового агента.

Об’єктом оподаткування ПДФО є заробітна плата, яка (відповідно до п. 14.1.48 ст. 144 ПК України) уміщує основну та додаткову заробітна плату, інші заохочувальні та компенсаційні виплати [1], які виплачуються (надаються) платнику податку у зв'язку з відносинами трудового найму згідно із законом, тобто це щомісячна заробітна плата, яка нарахована працівнику згідно зі штатним розкладом, трудовими договорами та табелем обліку робочого часу з урахуванням роботи у вихідні та святкові дні, у ненормований час, у нічний час тощо; податкової соціальної пільги відповідно до ПК України; щомісячної індексації заробітної плати, премій, надбавок, компенсацій, пільг, понаднормових, відпускних; виплат за рахунок фондів соціального страхування (лікарняні, відпустка за вагітністю та пологами, путивки тощо), медичного страхування, страхування життя; річного бонусу - «тринадцятої» зарплати або премії за підсумками року; інших нарахувань, передбачених законодавством України та колективним договором; заробітної плати за умов звільнення та скорочення.

База оподатковування ПДФО - грошова сума у гривнях нарахованої заробітної плати, яка відповідно до ПК України зменшується на суму єдиного внеску на загальнообов'язкове державне соціальне страхування страхових внесків до Накопичувального фонду, а у випадках, передбачених законом, обов'язкових страхових внесків до недержавного пенсійного фонду [21, с. 21], які сплачуються за рахунок заробітної плати працівника, 
а також на суму податкової соціальної пільги за їі наявності. Хоча з 2016 р. на підставі Закону України «Про внесення змін до Податкового кодексу України та деяких законодавчих актів України щодо забезпечення збалансованості бюджетних надходжень у 2016 році» від 25.12.2015 р. заробітна плата до оподаткування ПДФО не зменшується на суму єдиного внеску на загальнообов'язкове державне (ССB).

До 2016 р. із заробітної плати утримувався ЄСВ відповідно до Закону України «Про збір та облік єдиного внеску на загальнообов'язкове державне соціальне страхування» у розмірі 3,6\% - загальний розмір; 2,85\% - для осіб з інвалідністю - фізичних осіб; 6,1\% - політичних діячів, працівників бюджетних установ тощо [2].

При визначенні бази оподаткування платник має право скористатися податковою соціальною пільгою, на яку коригується загальний оподатковуваний дохід. Пільга може використовуватися виключно до заробітної плати тільки за одним місцем роботи i для ii отримання працівник повинен подати заяву роботодавцю. Держслужбовці подають лише підтверджувальні документи для встановлення розміру пільги.

Звернемо увагу на те, що Податковим кодексом України встановлені певні пільги щодо цього податку. Вони діляться на [1]:

1) місячні - податкова соціальна пільга - зменшення розміру заробітної плати, яка підлягає оподаткуванню, а також зменшення розміру ПДФО та збільшення розміру отриманої на руки заробітної плати.

Податкова соціальна пільга - сума, на яку платник податку на доходи фізичних осіб на підставі своєї заяви має право зменшити суму загального місячного оподатковуваного доходу, 
отримуваного від одного роботодавця за одним місцем роботи у вигляді заробітної плати та інших прирівняних до неї відповідно до законодавства виплат, компенсацій та винагород, якщо розмір такого місячного доходу не перевищує суми, що дорівнює розміру місячного прожиткового мінімуму, що діє для працездатної особи на 1 січня звітного податкового року (на 01.01.2018 р. - 1762,00 грн.), помноженого на 1,4 та округленого до найближчих 10 грн (1762,00 x 1,4 = 2470,00 грн.). Граничний розмір доходу, який дає право на отримання податкової соціальної пільги одному з батьків у випадку та у розмірі, визначається як добуток суми $(2470,00+2470,00)$, та відповідної кількості дітей.

Платник податку самостійно обирає місце застосування податкової соціальної пільги, якщо має на таке право, та подає роботодавцю заяву про іiі застосування. Пільгу розраховує роботодавець та вираховує іiі з заробітної плати працівника під час її нарахування. Розмір пільги [1]:

1) $50 \%$ (881,00 грн.) (до 01.01 .2016 р. було 100\%) розміру прожиткового мінімуму для працездатної особи (у розрахунку на місяць), встановленому законом на 1 січня звітного податкового року для будь-якого платника податку;

2) у розмірі від 50\% (станом на 2018 р. - 881,00 грн.) розміру прожиткового мінімуму для працездатної особи (у розрахунку на місяць), встановленому законом на 1 січня звітного податкового року:

- 100\% (881,00 грн.) для платника податку, який утримує двох чи більше дітей віком до 18 років, - у розрахунку на кожну таку дитину;

- 150\% (1321,50 грн.) для платника податку, який: є одинокою матір'ю (батьком), вдовою (вдівцем) або опікуном, піклувальником 
- у розрахунку на кожну дитину віком до 18 років; утримує дитинуінваліда - у розрахунку на кожну таку дитину віком до 18 років; $\epsilon$ особою, віднесеною законом до першої або другої категорій осіб, які постраждали внаслідок Чорнобильської катастрофи, включаючи осіб, нагороджених грамотами Президії Верховної Ради УРСР у зв’ язку з їх участю в ліквідації наслідків Чорнобильської катастрофи; є учнем, студентом, аспірантом, ординатором, ад’юнктом та ін.;

- 200\% (1762,00 грн.) для платника податку, який є Героєм України, Героєм Радянського Союзу, Героєм Соціалістичної Праці або повним кавалером ордена Слави чи ордена Трудової Слави, особою, нагородженою чотирма і більше медалями «За відвагу»; учасником бойових дій під час Другої світової війни або особою, яка у той час працювала в тилу, та особам з інвалідністю I і II групи, з учасників бойових дій на території інших країн у період після Другої світової війни, на яких поширюється дія Закону України «Про статус ветеранів війни, гарантії їх соціального захисту» та ін.;

3) річна - податкова знижка - повернення частини сплаченого за рік ПДФО. Податкова знижка - документально підтверджена сума (вартість) витрат платника податку - резидента у зв'язку з придбанням товарів (робіт, послуг) у резидентів - фізичних або юридичних осіб протягом звітного року, на яку дозволяється зменшення його загального річного оподатковуваного доходу, одержаного за наслідками такого звітного року у вигляді заробітної плати у випадках, визначених ПК України [1].

Якщо платник податку поніс певні витрати, які документально підтверджені та дозволені ПК України для включення до витрат, які дають право на податкову знижку, то він має право на підставі зазначеного за результатами року отримати повернення частини сплаченого ПДФО. Такими витратами є частина 
суми процентів, сплачених таким платником податку за користування іпотечним житловим кредитом; суму коштів, сплачених платником податку на користь вітчизняних вищих та професійно-технічних навчальних закладів для компенсації вартості здобуття середньої професійної або вищої освіти такого платника податку та/або члена його сім’ї першого ступеня споріднення тощо [1].

Таким чином, 3 вище зазначеного, можна визначити, що розмір податкової соціальної пільги не змінюється протягом податкового року і залежить від розміру мінімальної заробітної плати встановленої на 1 січня, проте недоліком є те, що гранична сума доходу до якої можна застосувати податкову соціальну пільгу також не змінюється, але номінальний рівень доходів громадян може зростати, що зумовлено плановими підвищеннями рівня мінімальної заробітної плати в країні та знеціненням грошей.

Слід зазначити, що сучасний податок на доходи фізичних осіб нараховується, утримується та сплачується (перераховується) до бюджету податковим агентом, який нараховує (виплачує, надає) оподатковану заробітну плату на користь платника податку та зобов'язаний утримувати податок із їі суми за його рахунок, використовуючи ставку ПДФО.

ПДФО сплачується (перераховується) до бюджету податковим агентом під час виплати заробітної плати єдиним платіжним документом. Банки приймають платіжні документи на виплату доходу лише за умови одночасного подання розрахункового документа на перерахування ПДФО до бюджету. Якщо заробітна плата виплачується готівкою 3 каси податкового агента, ПДФО сплачується (перераховується) до бюджету протягом трьох банківських днів із дня, що настає за днем такого нарахування (виплати, надання). 
Податковий агент про суми нарахованої заробітної плати та нарахованого, утриманого та сплаченого ПДФО обов'язково звітує за кожний квартал до органу Держаної податкової служби України шляхом подання протягом 40 календарних днів, що настають за останнім календарним днем звітного кварталу, Податкового розрахунку сум доходу, нарахованого (сплаченого) на користь фізичних осіб, і сум утриманого 3 них податку - 1ДФ у порядку, визначеному Наказом Міністерства фінансів України «Про затвердження форми Податкового розрахунку сум доходу, нарахованого (сплаченого) на користь фізичних осіб, i сум утриманого $з$ них податку (форма № 1ДФ) та Порядку заповнення та подання податковими агентами Податкового розрахунку сум доходу, нарахованого (сплаченого) на користь фізичних осіб, і сум утриманого з них податку».

Система оподаткування доходів фізичних осіб - це взаємопов'язана сукупність дій та методів оподаткування доходів резидентів та нерезидентів за безпосередньої участі податкового агента із застосуванням податкових фіскальних інструментів під впливом зовнішніх чинників.

Розглядаючи першу складову системи оподаткування доходів фізичних осіб, необхідно відмітити, що до неї відносять суб'єктів оподаткування, а саме: платників ПДФО, податкових агентів та Податкову інспекцію Державної податкової служби. Метою взаємодії суб'єктів є формування дохідної частини бюджету об'єднаних територіальних громад і виконання зобов'язань, покладених на фізичних осіб Податковим кодексом України. Податкові агенти виступають посередниками між платником через виконання своїх зобов'язань та фіскальними органами в дотриманні податкового законодавства (рис. 5.1). 


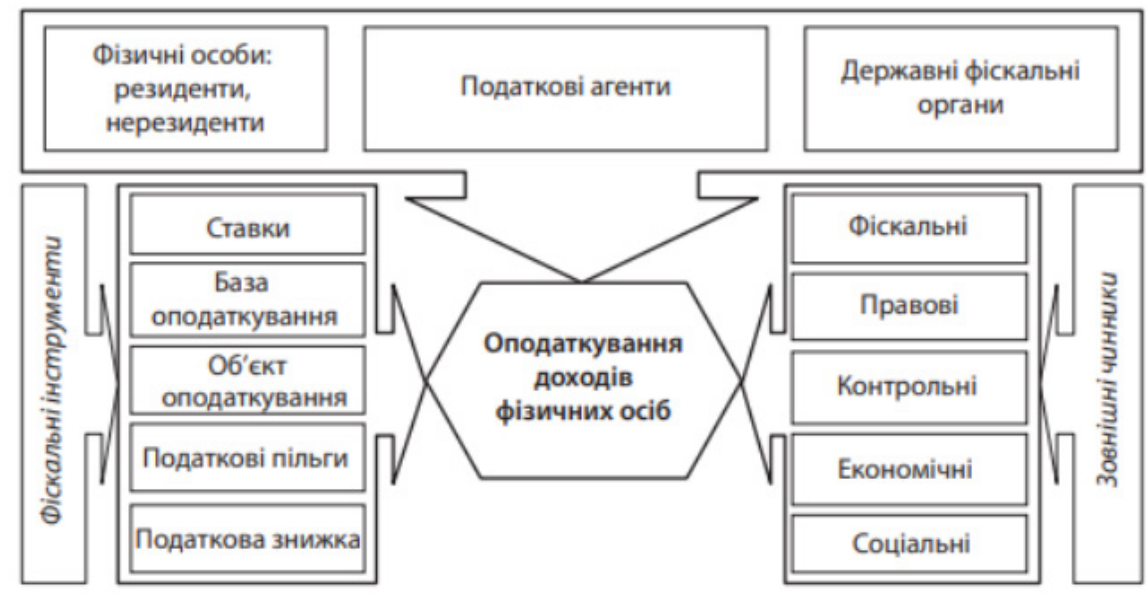

\section{1. Система оподаткування доходів фізичних осіб}

Джерело: систематизовано авторами

Підсистема зовнішніх чинників зобов'язує при адмініструванні податку враховувати фіскальні, правові, контрольні, соціальні та економічні функції 3 огляду на масштаб впливу некерованих факторів. Наразі особливо доречними стають політичні чинники. Наявність збройного конфлікту та вилучення значної частини платників податків негативно впливають на витратну i дохідну частини бюджетів.

Головною складовою системи оподаткування доходів фізичних осіб податком на доходи виступає організація оподаткування, яка передбачає певну послідовність дій податкового агента, спрямовану на чітке податкове трактування основних елементів оподаткування. Елементи оподаткування: доходи фізичних осіб, база оподаткування, ставки податку, податкові соціальні пільги та податкова знижка формують фіскальні інструменти оподаткування фізичних осіб, що застосовують роботодавці. Водночас доходи, які оподатковуються, формуються із доходів у 
вигляді заробітної плати, дивідендів, матеріального забезпечення 3 тимчасової втрати працездатності, сум винагород відповідно до умов цивільно-правового характеру, доходів від продажу майнових і немайнових прав, банківських відсотків, доходів від надання майна в оренду, інвестиційного прибутку, пасивних доходів, додаткового блага від роботодавця тощо.

Доходи, що не відносяться до розрахунку загального місячного оподатковуваного доходу (не обкладаються податком), включають в себе пенсії, суми державної та соціальної допомоги, державні премії чи стипендії, компенсаційні витрати на відрядження, допомогу на поховання, основну суму депозиту та інші.

Далі пропонуємо звернути увагу на порядок оподаткування фізичних осіб, які ведуть незалежну професійну діяльність. Так, на сьогоднішній день правове регулювання оподаткування доходів, отриманих фізичною особою, яка провадить незалежну професійну діяльність, здійснюється статтею 178 ПК України. Дана норма містить положення про те, що доходи громадян, отримані протягом календарного року від провадження незалежної професійної діяльності, оподатковуються також за ставкою 18\% бази оподаткування.

Оподатковуваним доходом вважається сукупний чистий дохід, тобто різниця між доходом і документально підтвердженими витратами, необхідними для провадження певного виду незалежної професійної діяльності. У разі неотримання довідки про взяття на облік особою, яка провадить незалежну професійну діяльність, об’єктом оподаткування є доходи, отримані від такої діяльності без урахування витрат.

Для того, щоб мати відповідний перелік прав та обов'язків фізичні особи-підприємці та особи, що мають намір провадити 
незалежну професійну діяльність, підлягають взяттю на облік як самозайняті особи у відповідних контролюючих органах на підставі ст. 65 глави 6 ПК України [1].

Отримання довідки про взяття на облік платника податків є важливим фактом і безпосередньо пов'язане з визначенням об'єкта оподаткування. Але контролюючі органи можуть відмовити від взяття на облік таких платників на основі визначених підстав:

- наявності обмежень на провадження незалежної професійної діяльності, встановлених законодавством;

- коли документи подані за неналежним місцем обліку;

- коли документи не відповідають встановленим вимогам, подані не в повному обсязі або коли зазначені в різних документах відомості є взаємно невідповідними;

- коли фізична особа вже взята на облік як самозайнята особа;

- неподання для реєстрації особою, яка має намір провадити незалежну професійну діяльність, свідоцтва про реєстрацію чи іншого документу (дозволу, сертифікату тощо), що підтверджує право фізичної особи на провадження незалежної професійної діяльності.

Якщо платник не отримав довідку про взяття на облік як особи, що здійснює незалежну професійну діяльність, то об’єктом оподаткування у нього будуть всі доходи, отримані від такої діяльності без урахування витрат.

Особи, що здійснюють незалежну професійну діяльність, оподатковуються як і фізичні особи-платники податків згідно із загальною системою за певним виключенням:

1) вони зобов’язані зареєструватись у контролюючих органах за місцем проживання як самозайняті особи;

2) основним критерієм для віднесення до видатків, що 
зменшують дохід для об'єкта оподаткування, є їх належність і необхідність для здійснення незалежної професійної діяльності.

Натомість, загальна система оподаткування для фізичних осіб-підприємців є найбільш складною 3 точки зору обліку та звітності. Не дивлячись на певні іiі переваги (не має обмежень кількості найманих працівників, не має обмежень у виборі виду діяльності), є певні недоліки (фізичні особи-підприємці зобов’язані вести облік та документально підтверджувати всі свої доходи та витрати та ін.). Така система більше підходить до фізичних осібпідприємців, які здійснюють свою діяльність несистематично i мають невисоку рентабельність продажів. Підприємець може опинитись на загальній системі «в покарання», якщо порушить умови перебування на спрощеній системі оподаткування.

Спрощена система має суттєві переваги порівняно із загальною. Це сплата фіксованої суми єдиного податку (в залежності від групи, до якої віднесено платника), звільнення від сплати деяких податків і зборів, ведення спрощеного обліку та звітності доходів і витрат.

Як бачимо, зазначені суб’ єкти хоча і входять до одного поняття «самозайнята особа», однак їх правове регулювання (система та порядок оподаткування) дещо різниться. Однак, що стосується їх прав та обов'язків, то в ПК України містяться норми (ст. 16, ст.17 ПК України), що стосуються основних (загальних) прав та обов'язків для всіх суб'єктів оподаткування, але цей перелік не є вичерпним. Тобто, якщо в інших статтях зазначеного нормативно-правового акту будуть посилання на додаткові види прав та обов'язків, які не визначені ст. 16 та ст. 17 ПК України для таких суб’єктів, то вони також можуть бути застосованими. Наприклад, в пп. 177.4.6 п.177 ст. 177 ПК України зазначено, що фізичні особи-підприємці, які 
отримують дохід від провадження господарської діяльності, крім осіб, що обрали спрощену систему оподаткування, мають право (за власним бажанням) включати до складу витрат, пов'язаних 3 провадженням їх господарської діяльності, амортизаційні відрахування з відповідним веденням окремого обліку таких витрат [1]. В даному випадку таке право не було зазначене в основному переліку прав, тому воно є додатковим, а отже, також може бути використане вищезазначеним суб'єктом оподаткування.

Фізичні особи, які провадять незалежну професійну діяльність, подають податкову декларацію за результатами звітного року відповідно до цього розділу у строки, передбачені для платників податку на доходи фізичних осіб. Іноземці та особи без громадянства, які стали на облік у контролюючих органах як самозайняті особи, є резидентами і у річній податковій декларації поряд 3 доходами від провадження незалежної професійної діяльності мають зазначати інші доходи з джерел їх походження з України та іноземні доходи.

Крім цього, особа, яка здійснює незалежну професійну діяльність, відповідно до наказу Державної податкової служби України від 16.09.2013 № 481 «Про затвердження форми Книги обліку доходів і витрат, яку ведуть фізичні особи-підприємці, крім осіб, що обрали спрощену систему оподаткування, i фізичні особи, які провадять незалежну професійну діяльність, та Порядку ії ведення» зобов'язана подати до контролюючого органу за основним місцем обліку примірник Книги обліку та витрат, на титульному аркуші якої зазначаються: прізвище, ім'я та по батькові, реєстраційний номер облікової картки платника податків або серія та номер паспорта, податкова адреса, номер та дата свідоцтва про право на здійснення НПД (за наявності). За результатами звітного року до 1 травня необхідно подати податкову декларацію про майновий стан і доходи. 
Отже, проаналізувавши норми ПК України, слід зазначити, що законодавець досить детально обдумав, визначив, закріпив та удосконалив порядок оподаткування заробітної плати ПДФО, тобто суттєвих недоліків ПДФО із заробітної плати немає, крім, на нашу думку, таких недоліків, як:

- щодо ставки податку, яка не є соціально справедливою, яка порушує фундаментальний принцип оподаткування - соціальної справедливості та через яку відбувається ухилення від сплати ПДФО, що є проблемою для України, оскільки це ухилення $є$ порушенням законодавства, розширює межі тіньової економіки та наслідком недоотримання усього обсягу податку до бюджету;

- щодо частини положень, що регулюють податкову соціальну пільгу та податкову знижку;

- відповідно до ст. 9 ПК України ПДФО є загальнодержавним, а не місцевим, і відповідно до Бюджетного кодексу України не повністю надходить до місцевих бюджетів, а тільки частково.

Отже, оскільки податок із доходів фізичних осіб має скерованість на соціальну справедливість, то ставить рівень оподаткування в пряму залежність від обсягів доходу платника. Соціалізованими податковими інструментами можна вважати податкову соціальну пільгу та податкову знижку.

На нашу думку, оподаткування доходів фізичних осіб можна розглядати з позиції триєдиного підходу, що характеризує його як явище, процес і систему:

1) оподаткування трактується як явище, в якому відображається формування комплексу організаційних та економічних умов, виявляється зовнішній вплив на оподаткування, рівень застосування податкових інструментів;

2) процесом оподаткування потрібно вважати комплекс 
послідовних дій, спрямованих на досягнення наповнення бюджетів;

3) під системою оподаткування розуміють сукупність взаємопов’язаних елементів, їх цілісну єдність та взаємодію із зовнішнім і внутрішнім середовищем.

\section{Практичні аспекти адміністрування податку на доходи} фізичних осіб в Україні. Оподаткування доходів фізичних осіб є однією з пріоритетних складових збалансованої політики держави у соціальному секторі. Підтвердженням цього є прописане в Конвенції МОП № 117 «Про основні цілі та норми соціальної політики», де зазначено: «...всяка політика повинна, перш за все, спрямовуватися на досягнення добробуту і розвитку населення, а також на заохочення його прагнення до соціального прогресу».

Після прийняття ПК України та закріплення в ньому поняття «адміністрування податків, зборів, митних платежів, єдиного внеску на загальнообов’язкове державне соціальне страхування та інших платежів відповідно до законодавства, контроль за дотриманням якого покладено на контролюючі органи», яке ми можемо скорочено називати «фіскальне адміністрування», у наукових працях переважає визначення правової категорії «адміністрування податків» («податкове адміністрування») із застосуванням так званого «елементарного підходу», коли до дефініції поняття включають всі його елементи, а в нашому випадку - завдання, функції, стадії, суб'єктів зазначеного виду владної діяльності та кола підвладних суб'єктів.

У підп. 14.1.11 ПК України закріплене поняття «адміністрування податків, зборів, митних платежів, єдиного внеску на загальнообов'язкове державне соціальне страхування та інших платежів відповідно до законодавства, контроль за дотриманням якого покладено на контролюючі органи», що розуміється як 
сукупність рішень та процедур контролюючих органів i дій їх посадових осіб, що визначають інституційну структуру податкових та митних відносин, організовують ідентифікацію, облік платників податків і платників єдиного внеску та об'єктів оподаткування, забезпечують сервісне обслуговування платників податків, організацію та контроль за сплатою податків, зборів, платежів відповідно до порядку, встановленого законом.

Слід зазначити, що в зарубіжній та вітчизняній економічній літературі у більшості випадків автори виділяють зовнішні та внутрішні фактори впливу на діяльність будь-якої системи. Важливість зовнішніх факторів також залежить від ступеня їх впливу на оподаткування доходів фізичних осіб, тому доцільним буде сформувати перелік основних факторів зовнішнього середовища (непрямої дії) для подальшого визначення значущості їх впливу на оподаткування (рис. 5.2).

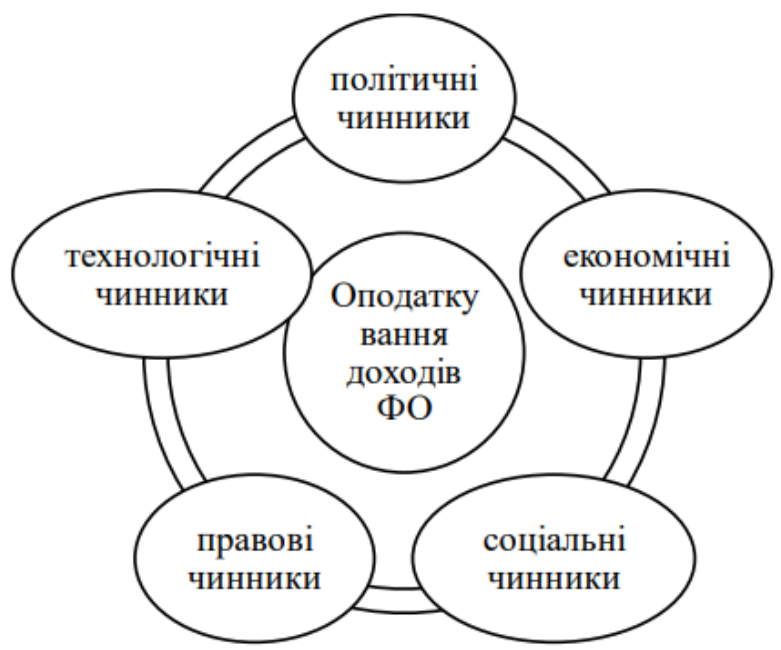

Рис. 5.2. Чинники зовнішнього впливу на оподаткування доходів фізичних осіб

Джерело: систематизовано авторами 
Варто відзначити, що наразі особливо доречними стають політичні чинники. Наявність військового конфлікту та вилучення значної частини платників податків негативно впливають на витратну і дохідну частину бюджету. Слід відзначити, що значущість соціальної компоненти полягає в тому, що вона впливає не лише на фіскальні органи, а й на внутрішнє середовище платників податків. Ріст мінімальної заробітної плати та диверсифікація доходів платників змінюються досить повільно. Так, на думку С. Ковач, податковий агент, здійснюючи виплату (надання) платнику доходу, має, перш за все, вірно його класифікувати, адже від цього залежить його подальше оподаткування.

Аналіз технологічного аспекту функціонування податкової системи дає змогу своєчасно виявляти ті можливості, які за рахунок розвитку інтернет-технологій відкриваються для формування нових податкових продуктів та удосконалення діючих норм нарахування, сплати та адміністрування податків. Тому, за побудови й застосуванні обраної стратегії, платники, податкові агенти та Державна податкова служба мають своєчасно реагувати назміни зовнішнього середовища, виявляти фактори, які впливають на ці зміни, знаходити необхідні засоби адаптації до умов, що склалися.

Оцінка внутрішніх чинників вибору стратегії оподаткування доходів фізичних осіб повинна базуватися на моніторингу внутрішнього потенціалу податку: достовірності визначення об’єкту та бази оподаткування, ставок податку з доходів, податкових соціальних пільг та податкових знижок.

Крім того, внутрішніми перевагами можуть бути: ведення реєстру платників, електронне декларування, наявність програмного забезпечення, кваліфіковані кадри тощо.

Практичні аспекти адміністрування ПДФО можливо 
побачити через визначення впливу податкового навантаження на доходи фізичних осіб. Так, проаналізувавши структуру надходжень до державного бюджету України за роками, відмічено, що саме за рахунок оподаткування доходів фізичних осіб бюджет формується в межах 20\%.

Величина податкового навантаження на доходи фізичних осіб залежить як від доходів отриманих у формі заробітної плати, так і інших доходів. У таблиці 5.1 нами представлено динаміку зміни податкового тиску на доходи фізичних осіб.

Таблиияя 5.1

\section{Динаміка зміни податкового тиску на доходи фізичних осіб}

\begin{tabular}{|l|c|c|c|c|c|c|c|}
\hline \multirow{2}{*}{ Показники } & \multicolumn{5}{|c|}{ Роки } & $\begin{array}{c}\text { Відхилення } \\
2018 / 2014, \\
+/-\end{array}$ & $\begin{array}{c}\text { Відхилення } \\
\text { П2018/2014, } \\
\%\end{array}$ \\
\cline { 2 - 7 } $\begin{array}{l}\text { Розмір } \\
\text { мінімальної } \\
\text { заробітної } \\
\text { плати, грн }\end{array}$ & 1378 & 1450 & 1600 & 3200 & 4173 & +2795 & $+203 \%$ \\
\hline $\begin{array}{l}\text { Величина } \\
\text { прожиткового } \\
\text { мінімуму, грн }\end{array}$ & 1378 & 1400 & 160 & 1762 & 1921 & +543 & $+39 \%$ \\
\hline
\end{tabular}

Слід зазначити, що розмір прожиткового мінімуму та мінімальна зарплата $\epsilon$ різними соціальними показниками i уже декілька років вони не збігаються за величиною. Крім того, впродовж року величина прожиткового мінімуму змінюється, при чому вона $є$ різною для різних категорій населення.

Динаміку зміни величини прожиткового мінімуму нами представлено в таблиці 5.2. 
Таблиия 5.2

Динаміка величини прожиткового мінімуму за категоріями

населення впродовж 2019 року

\begin{tabular}{|l|c|c|c|c|c|c|}
\hline \multirow{2}{*}{\multicolumn{1}{|c|}{ Категорія осіб }} & \multicolumn{5}{|c|}{ Прожитковий мінімум, грн } \\
\cline { 2 - 7 } & $\mathbf{0 1 . 0 1}-\mathbf{3 0 . 0 6}$ & $\mathbf{0 1 . 0 7}-\mathbf{3 0 . 1 1}$ & $\mathbf{0 1 . 1 2}-\mathbf{3 1 . 1 2}$ \\
\cline { 2 - 8 } & $\mathbf{2 0 1 8}$ & $\mathbf{2 0 1 9}$ & $\mathbf{2 0 1 8}$ & $\mathbf{2 0 1 9}$ & $\mathbf{2 0 1 8}$ & $\mathbf{2 0 1 9}$ \\
\hline Діти до 6 років & 1492 & 1626 & 159 & 1699 & 1626 & 1776 \\
\hline Діти від 6 до 18 років & 1860 & 2027 & 1944 & 2118 & 2027 & 2218 \\
\hline Для працездатних осіб & 1762 & 1921 & 1841 & 2007 & 1921 & 2102 \\
\hline $\begin{array}{l}\text { Для осіб, які втратили } \\
\text { працездатність }\end{array}$ & 1373 & 1497 & 1435 & 1564 & 1797 & 1638 \\
\hline Загалом & & 1853 & & 1936 & & 2027 \\
\hline
\end{tabular}

За даними зведеної таблиці варто відмітити, що за роками (2018-2019 рр.) величина прожиткового мінімуму зростає як за періодами року, так і за роками. В процесі планування господарської діяльності підприємства керівному персоналу слід звернути на це увагу, оскільки ці зміни викликають збільшення витрат підприємства, які необхідно передбачити на стадії планування. Зміна цього показника має вплив на низку показників і соціальних гарантій, на основі якого вони розраховуються. Проте, ця величина прожиткового мінімуму є не співвимірною із реальною здатністю забезпечити мінімальні соціальні гарантії для певних категорій населення. Зміна прожиткового мінімуму із величини 1762 грн станом на 1 січня 2018 року до величини 1921 грн у аналогічному періоді 2019 року (зростання на 9\%) не відповідає показнику інфляції за рік.

3 роками розмір мінімальних доходів фізичних осіб в Україні зростає - 3200 у 2017 році до 4173 грн. у 2019 році. Збільшення цього показника несе за собою зміну інших величин, які розраховуються на його основі. Так, розмір мінімальної заробітної плати впливає на: 
- ставку єдиного податку платників 2 групи, який розраховується як 20\% від величини мінімальної заробітної плати;

- розмір максимальної бази $\mathrm{CCB}$, що визначається як 15 мінімальних заробітних плат;

- розмір добових, який визначається як 0,1 мінімальна заробітна плата;

- розмір штрафних санкцій за порушення законів України «Про працю»;

- обмеження розміру оплати декретних;

- розрахунок розміру штрафних санкцій за неподання звіту про неконтрольовані операції (до розрахунку береться 200-300 мінімальних зарплат);

- розмір збору з місць паркування транспортних засобів (визначається як 0,03-0,1\% від мінімальної заробітної плати);

- розрахунок суми податку на нерухомість (визначається як 2\% від мінімальної заробітної плати за $\left.1 \mathrm{~m}^{2}\right)$;

- сума неоподаткованих подарунків призерам змагань (розрахунок проводиться як 50\% від мінімальної зарплати);

- величина мінімального розміру статутного капіталу акціонерних товариств (визначається як 1250 розмірів мінімальних заробітних плат).

Iз проведеного нами аналізу варто відмітити, що із зростанням розміру мінімальної заробітної плати збільшується величина усіх розрахованих на ii основі показників. Судити про позитивне чи негативне значення такого зростання ми не можемо однозначно, оскільки це явище має двояке значення: з однієї сторони, збільшується мінімальна величина доходів фізичних осіб, а з іншої - збільшується податкове навантаження як на працедавця, так і на величину доходу безпосередньо таких осіб. 
Звернемо увагу на те, що щорічно в рамках рейтингу DoingBusiness, аудиторська компанія $\mathrm{PwC}$ і Група Світового Банку проводять спільне дослідження податкових систем «PayingTaxes» в 190 країнах світу. У цьому рейтингу враховується кількість податкових платежів, загальна ставка оподаткування, час, необхідний на підготовку та подачу податкової звітності, індекс постподачі (оцінює відносну ефективність роботи податкових органів після подачі податкової звітності за двома напрямами: виправлення помилки у звітності 3 податку на прибуток та декларування бюджетного відшкодування ПДВ). Даний рейтинг оцінює легкість ведення бізнесу в країні, оскільки аналізується сегмент середнього бізнесу (умовнепідприємство 3 100\% українських акціонерів, 31 млн грн - річний прибуток, 60 співробітників та підприємство проводить лише операції на внутрішньому ринку). Звіт на кожен наступний рік оприлюднюється восени поточного року за даними минулого року.

Період 2014-2018 pр. був достатньо насиченим у контексті реформування оподаткування доходів фізичних осіб, які, з однієї сторони, були спрямовані на підвищення фіскальної ефективності ПДФО, а з іншої - на детінізацію доходів населення. Як показав проведений аналіз, запровадження базової ставки ПДФО у розмірі $18 \% 2016$ р. призвело до збільшення надходжень. Так, за I квартал 2016 р. вони становили 28,7 млрд грн, що перевищило показник I кварталу 2015 р. на 40\%. Одночасно відбулося зменшення надходжень ЄСВ на 25\%, що пов'язане зі зниженням ставки до $22 \%$. Україна в рейтингу «Оподаткування 2018» піднялася на 43 позицію з 190 країн порівняно з 84 місцем за результатами рейтингу «Оподаткування 2017». Найбільш вплинуло на покращення позицій у рейтингу зниження єдиного соціального внеску з 2017 року. Це 
мало позитивний вплив на загальне податкове навантаження в Україні.

Як свідчать дані оприлюдненого дослідження, Україна порівняно з показниками минулого року поліпшила свої позиції майже вдвічі - на 41 процентний пункт. Згідно з оприлюдненими даними, загальне податкове навантаження в Україні складає 37,8\%, в Свропейському Союзі - 40,5\%, тоді як загальний світовий показник - 39,6\%. Позитивний тренд Україна показує відносно кількості податкових платежів на рік - їх п’ять, при середньому показнику в світі - 24, в СС - 12. Водночас на підготовку та подання податкової звітності в Україні в середньому йде 327,5 години на рік, тоді як в ЄС цей показник - 161 година, а загальний світовий - 240 годин, свідчать дані рейтингу «Оподаткування-2018». За індексом постподання український показник досяг 85,95 при загальному світовому в 59,51 і європейському - 81,6. Дослідження «Оподаткування-2018» (PayingTaxes 2018) є однією зі складових дослідження «Ведення бізнесу 2018» (Doing Business 2018) та є щорічним спільним проєктом Групи Світового банку і компанії РwC, в рамках якого оцінюються кількісні та якісні аспекти сплати податків в 190 країнах.

Такі тенденції, зазвичай, можна оцінювати як позитивні результати, втім їх ефективність потрібно характеризувати через фіскальний прояв і через окреслення різних періодів економічного розвитку суспільства. Так, рисунок 5.3 містить інформацію про вагу основних податків у ВВП та податкових надходженнях країн СС та в Україні у 2018 році.

У макроекономічному масштабі податкове навантаження відображає ефективність податкової політики, тобто кількісно вимірює сукупний вплив податкових платежів на джерела їхньої сплати. У міжнародній практиці цей показник визначається як 
відношення фактичних податкових надходжень у зведений бюджет до обсягу валового внутрішнього продукту. За цим методом визначатимемо рівень податкового навантаження в Україні (рис. $5.3)$.

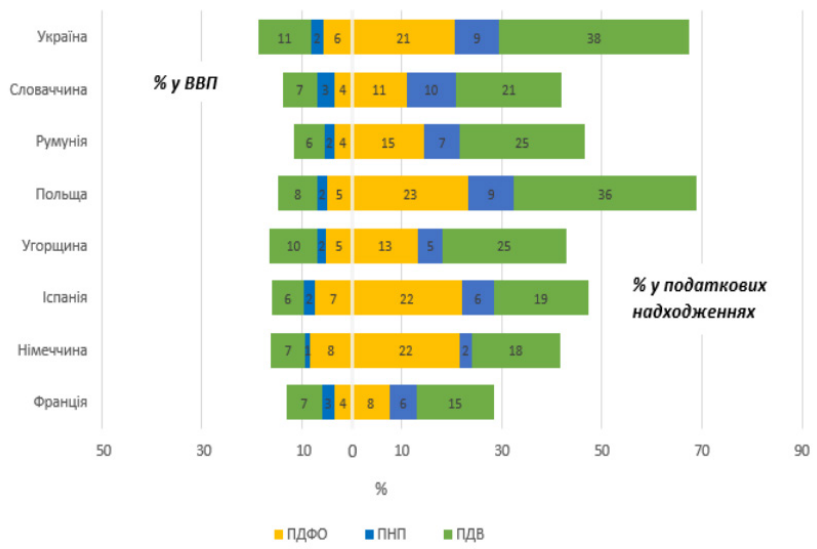

\section{Рис. 5.3. Вага основних податків у ВВП та податкових надходженнях країн СС та в Україні}

Податкове навантаження на вітчизняну економіку зменшилося з прийняттям ПК України. Соціально-економічні умови розвитку й елементи державного управління є саме тими ключовими чинниками, що визначають оптимальний рівень податкового навантаження, а також, безумовно, ефективність використання податкових надходжень у процесі розподілу та перерозподілу ВВП і рівень задоволеності потреб населення.

Порівняно 3 іншими країнами, номінальний рівень податкового навантаження в Україні не більший, ніж у США, Канаді, Великобританії та Німеччині, проте реальне податкове навантаження, яке враховує рівень задоволення потреб платників, $є$ значно більшим (рис. 5.4). 


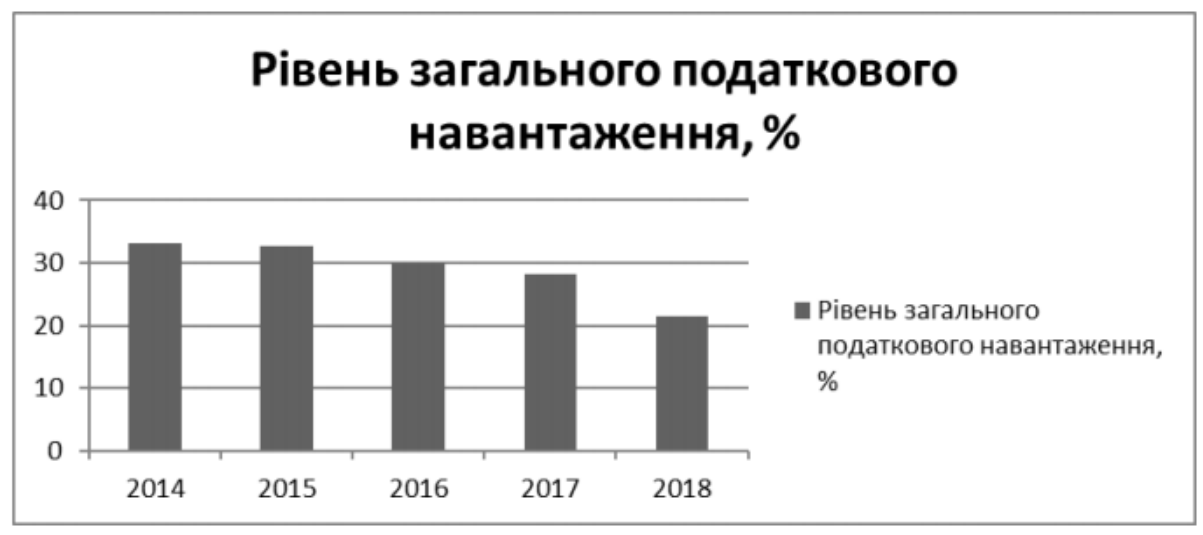

Рис. 5.4. Динаміка зміни загального рівня податкового навантаження в Україні у 2014-2018 рр.

Так, порівняно, наприклад, із соціально орієнтованою Швецією, де величина податкового тягаря становить близько 55\% ВВП, в Україні рівень податкового навантаження $є$ значно меншим і коливається в межах 33-36\%.

Проте твердження, що податкове навантаження для шведів більше, ніж для українців, $є$ помилковим, оскільки частка податків, що повертається населенню при перерозподілі доходів бюджету, для перших становить близько 85\%, тоді як у нас вона не перевищує $30 \%$.

Для проведення аналізу рівня податкового навантаження в країнах СС використаємо показник загального податкового навантаження, розрахований як відношення суми податків i обов'язкових соціальних внесків (скоригованих на суму безнадійної заборгованості) до обсягу ВВП. Результати розрахунку цього показника для країн СС у 2018 р. подані на рис. 5.5. 


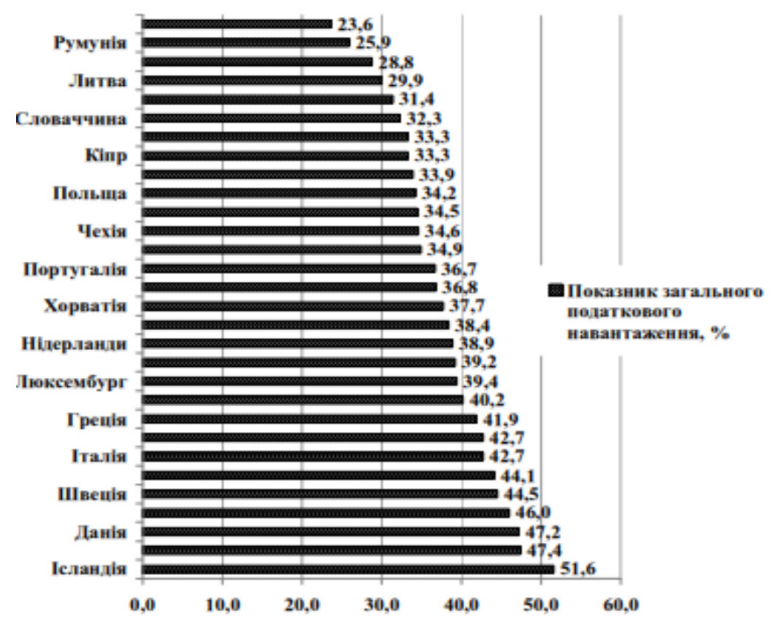

\section{Рис. 5.5. Рівень податкового навантаження в країнах Свропейського Союзу в 2018 р.}

Різниця між рівнями податкового навантаження у країнах ЄС є суттєвою: найнижчий показник податкового навантаження в Румунії $(23,6 \%)$ є майже вдвічі меншим, ніж найвищий показник у країнах $\mathrm{CC}$, а саме у Ісландії (51,6\%). Такі відмінності у рівнях податкового навантаження зумовлені як різними підходами до встановлення виду і розміру податкових ставок, об'єктів і баз оподаткування, так і різним рівнем економічного розвитку та обсягу ВВП досліджуваних країн.

В середньому ж загальне податкове навантаження в усіх країнах СС у 2018 р. становило 40\%. В країнах, що не $\epsilon$ членами $\mathrm{CC}$, рівень податкового навантаження перебуває в межах загальноєвропейського рівня.

Нині в країнах Європейського Союзу не існує єдиного пропорційного рівня податкового навантаження. Тому розглянемо таблицю податкового навантаження усіх країн членів СС. Для більшості країн характерним $є$ помірне податкове навантаження 
та проведення податкової політики, спрямованої на забезпечення стабільного економічного зростання, створення сприятливого клімату для розвитку господарської діяльності та ефективного вирішення соціальних проблем у державі.

Звернемо увагу на те, що у рейтингу сприятливості податкових систем Paying Taxes 2015, підготовленому Світовим банком спільно з PricewaterhouseCoopers, Україна посіла 126 місце серед 183 досліджуваних країн, але починаючи з 2016 показники суттєво покращились. Таким чином, Україна $(35,4 \%)$ знаходиться в одній групі з такими країнами як Великобританія (33,5\%), Естонія (34,9\%), Португалія (34,3\%), Польща (33,6\%), Чехія (34,5\%), а також Хорватія $(37,8)$.

У міжнародних рейтингах прозорості та легкості ведення бізнесу «Doing Business 2017» Україна посіла 70-е місце серед 185 країн. Одним із компонентів рейтингу є показник «Оподаткування». У зв’язку з податковою реформою в Україні, рівень податкового тягаря, а також кількість і тривалість виплат поступово зменшується. Окрім того, у зв'язку з здійсненням подачі податкових звітів до податкового органу державної податкової служби тільки в електронному вигляді для платників податків, що належать до великих та середніх підприємств, тривалість процесу сплати податків в Україні скоротилася на 166 годин.

Досить тісний зв'язок існує між показником податкового навантаження та внутрішнім валовим продуктом. У країнах, які перебувають у першій половині рейтингу Світового банку та мають вищу оцінку ефективності податкової системи, середній рівень ВВП на одну особу становить 29,2 тис. дол. У другій половині країн, 3 нижчою оцінкою ефективності податкової системи, середній рівень ВВП на особу становить менш, як 5,3 тис. дол. Середня оцінка 
ефективності податкової системи за рейтингом у другій половині країн гірша втричі, а ВВП на особу - у шість разів.

Різні рівні податкового навантаження у різних країнах пояснюються особливостями соціально-економічного розвитку, фінансової політики та механізмом побудови податкової системи. Негативний вплив на економічний та соціальний розвиток країни здійснюється внаслідок тінізації економіки, недосконалого механізму справляння податків, зборів та інших обов'язкових платежів, неефективних податкових пільг, низького рівня податкової культури та податкової дисципліни суб'єктів господарювання.

На рисунку 5.6 зображено порівняльну динаміку податкового навантаження в країнах ЄС-27 та України за останні п’ять років.

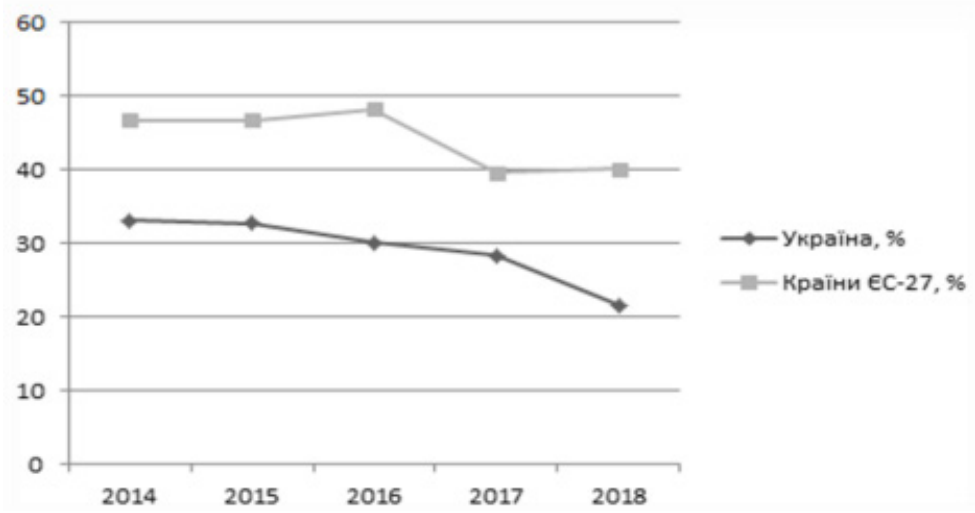

\section{Рис. 5.6. Порівняльна динаміка податкового навантаження в країнах ЄС-27 та України за 2014-2018 рр.}

Досліджуючи фіскальну ефективність ПДФО, варто відзначити її залежність від двох ключових чинників:

- розміру і диференціації ставок оподаткування та величини i структури бази оподаткування, зокрема наявності податкових пільг. Щодо першого, то наразі в Україні цей податок функціонує 
на пропорційній основі (з 2016 року базова ставка щодо більшості доходів становить 18\%). Але в попередні періоди, рухаючись у зворотному напрямі, діяли мало прогресивна шкала оподаткування (у 2015 році - 15\% і 20\%, з 2011 року по 2014 рік - 15\% і 17\%), пропорційна (з 2007 року по 2010 рік - 15\%, з 2004 року по 2006 рік - 13\%) та прогресивна (від часів набуття незалежності й до 2003 року включно) з максимальною ставкою 50\% на момент переходу до пропорційної моделі даного податку [1].

Що ж до чинника величини бази оподаткування, то простежується пряма залежність між підвищенням обсягів мобілізації до відповідних бюджетів податку на доходи фізичних осіб в абсолютному вимірі (протягом 2010-2018 років вони виросли більш, ніж в 2,7 рази) та зростанням номінальних доходів населення. На користь цього, зокрема, свідчить динаміка середньомісячної заробітної плати в нашій державі, особливо зважаючи, що для українців праця виступає основним джерелом їх доходів.

Також ПК України передбачено низку доходів, що не включаються до бази оподаткування, можливість застосування податкової знижки з ПДФО у разі понесення платником витрат на визначені в ПК України цілі, а також наявність податкової соціальної пільги (ПСП) для осіб з низькими доходами. Остання застосовується до доходу, отримуваного лише від одного роботодавця у вигляді заробітної плати, якщо його розмір не перевищує суми, що дорівнює розміру місячного прожиткового мінімуму, законодавчо встановленого для працездатної особи на 1 січня звітного податкового року, помноженого на 1,4 та округленого до найближчих 10 гривень.

Реалізація фіскальної функції прибуткового оподаткування населення характеризується вищою ефективністю, ніж регулюючої, 
зважаючи на означені проблемні аспекти функціонування податкової знижки з ПДФО і податкової соціальної пільги, а також пропорційний підхід до податкового перерозподілу доходів фізичних осіб. Тому українське суспільство потребує світоглядного i практичного перегляду його місця й ролі у фіскальній політиці держави.

Отже, незважаючи на розпочаті реформи, податкова система України недосконала і має проблеми, які потребують негайного вирішення. Стягування податків в Україні є достатньо високим і гальмує розвиток економіки. Важливим завданням $є$ оптимізація податкового навантаження. Необхідно віднайти рівновагу між тягарем і вигодами оподаткування, між примусом i свідомим вибором сплати податків та зборів, тобто забезпечити баланс потреб і можливостей держави і промисловості, публічними і приватними інтересами. Для цього необхідно забезпечити:

- зменшення податкового навантаження на суб'єкти господарювання завдяки поступовому зниженню податкових ставок та розширення баз їх оподаткування. Зростання надходжень до бюджету має здійснюватися за рахунок збільшення кількості платників податків;

- покращення системи податкового адміністрування податків та зборів, забезпечення іiі прозорості;

- помірне зниження і пропорційність розподілу податкового навантаження між платниками залежно від виду діяльності;

- вдосконалення систем податкового контролю, які запобігають ухиленню платників від сплати податкових платежів;

- зменшення та ефективне використання податкових пільг, які дуже часто лобіюють інтереси зацікавлених осіб. Зниження загальної кількості податкових пільг та ретельна перевірка 
сприятимуть формуванню справедливої податкової системи;

- створення умов для активізації інвестиційних та інноваційних процесів у пріоритетних галузях економіки. Збільшення кількості інвестицій у господарську діяльність підприємств розширить масштаби їх діяльності та доходи суб’єктів господарювання. Зростання доходів призведе до збільшення ВВП і зменшення податкового навантаження.

Натепер в Україні потреба зменшення податкового навантаження не викликає жодних сумнівів, однак при цьому це зниження повинно бути поступовим та супроводжуватись зниженням витрат із державного бюджету. Крім того, слід звернути увагу і на те, що, окрім вказаного вище, проведення податкової реформи, зокрема, в частині зниження податкового навантаження повинно проводитись разом зі змінами у сфері оплати праці, а також економічно обгрунтованого розширення пакета соціальних послуг i гарантій працюючому населенню.

Податкова політика нашої держави в умовах імплементації Угоди про асоціацію з СС має розроблятися з урахуванням таких детермінант: з огляду на значні відмінності оподаткування країн СС немає потреби в докорінних змінах в оподаткуванні України у напрямі його «приведення до єдиного зразка»; податкова політика в Україні має враховувати як особливості податкової гармонізації (передусім вимоги Угоди про асоціацію щодо адаптації вітчизняного податкового законодавства до низки Директив $\mathrm{CC}$ із ПДВ і специфічних акцизів), так і сучасні тенденції податкових трансформацій у країнах $\mathrm{CC}$; особливості економіко-інституціонального середовища в нашій державі зумовлюють необхідність пошуку вітчизняного «ноу-хау» в податковому реформуванні. Але при цьому важливо враховувати досвід змін в оподаткуванні країн ЄС (насамперед 
постсоціалістичних учасників інтеграції) за схожих економічних і фіскальних умов.

Законом України від 14.11.19 р. № 294-IX «Про Державний бюджет України на 2020 рік» встановлено нові соціальні стандарти на 2020 рік - розміри мінімальної заробітної плати та прожиткового мінімуму. Зазначені стандарти безумовно впливатимуть на низку показників з оплати праці, порядок оподаткування доходів, зокрема на розміри податкової соціальної пільги та розмір доходів, який дає право на їі застосування, мінімальний розмір ССВ, розмір єдиного податку та податку на нерухоме майно тощо.

Враховуючи вище зазначене, варто знати наступне:

- $\quad$ відповідно до ст. 8 Закону про Держбюджет мінімальну заробітну плату (МЗП) установлено на весь рік у єдиному розмірі: у місячному розмірі - 4723 грн; у погодинному розмірі - 28,31 грн. Цей розмір МЗП впливатиме на наступні показники.

Неоподатковуваний розмір добових - в межах України 472,30 грн. на день.

- витрати на відрядження, не підтверджені документально, на харчування та фінансування інших власних потреб фізичної особи (добові витрати), понесені у зв’язку з таким відрядженням у межах території України, не включаються до оподатковуваного доходу, але не більш як 0,1 розміру МЗП, установленої законом на 1 січня податкового (звітного) року, у розрахунку за кожен календарний день такого відрядження. Таким чином, у 2020 році добові витрати під час відрядження по Україні не обкладаються податком на доходи фізичних осіб (ПДФО) та військовим збором (В3), якщо їх розмір не перевищує 472,30 грн. на день. Для відряджень за кордон добові витрати в розрахунку за кожен календарний день відрядження залишилися на рівні минулого року та становлять не більш як 80 
євро.

Максимальна величина бази нарахування ССВ становить 15 розмірів МЗП, отже, протягом усього 2020 року вона становитиме 70845 грн. Мінімальний страховий внесок з ССВ становить 139,06 грн (4723 грн х 22\%).

- $\quad$ єдиний внесок у розмірі не менше мінімального (1039,06 грн. за місяць) зобов’язані сплачувати підприємці (незалежно від обраної ними системи оподаткування) та фізичні особи, які ведуть незалежну професійну діяльність, члени фермерського господарства, якщо вони не належать до осіб, які підлягають страхуванню на інших підставах. Звільняються від сплати ССВ «за себе» пенсіонери за віком, особи з інвалідністю та особи, які отримують відповідно до закону пенсію або соціальну допомогу.

Неоподатковувана нецільова благодійна допомога - розмір такої допомоги у 2020 році становить 2940 грн.

- не включається до оподатковуваного доходу, а отже, не обкладається ПДФО та В3, нецільова благодійна допомога, у тому числі матеріальна, що надається резидентами - юридичними або фізичними особами на користь платника податку протягом звітного податкового року сукупно в розмірі, що не перевищує суми граничного розміру доходу, визначеного згідно з абзацом першим пП. 169.4.1 Податкового кодексу. Тобто, розмір неоподатковуваної нецільової благодійної допомоги 2020 року становить 2940 грн. Сума перевищення нецільової допомоги над зазначеним розміром включається до загального місячного (річного) оподатковуваного доходу платника податку як інші доходи і підлягає обкладенню ПДФО за ставкою 18\% і В3 - 1,5\%. Сума нецільової благодійної допомоги, у тому числі та, що перевищує встановлений граничний розмір, відображається в податковому розрахунку за ф. №1ДФ 3 
ознакою доходу «169».

- неоподатковувані дитячі подарунки та квитки. Вартість святкових подарунків і квитків на новорічно-різдвяні заходи в період з 15 листопада 2019 року до 15 січня 2020 року не включається до загального оподатковуваного доходу фізичних осіб-батьків, які отримали дитячі святкові подарунки від органів державної влади, органів місцевого самоврядування, громадських (у т. ч. профспілкових) організацій та створених ними закладів освіти, охорони здоров'я і культури, що утримуються за рахунок коштів відповідних бюджетів (ст. 3 Закону від 30.11.2000 р. №2117III «Про звільнення від оподаткування грошових коштів, які спрямовуються на проведення новорічно-різдвяних свят для дітей та на придбання дитячих святкових подарунків»). Під дитячими святковими подарунками в розумінні цього закону маються на увазі набори товарів, які містять лише кондитерські вироби та іграшки вітчизняного виробництва і фрукти, загальною вартістю не більше 8\% ПМ для працездатної особи, установленого законом на 1 січня звітного податкового року. Отож, неоподатковувана вартість дитячих святкових подарунків становить 168,16 грн (2102 грн х 8\%), якщо такі подарунки отримано з 1 січня до 15 січня і з 15 листопада до 31 грудня 2020 року.

\section{Проблеми та шляхи удосконалення оподаткування доходів} фізичних осіб в Україні. Сучасний механізм системи оподаткування доходів фізичних осіб в Україні не позбавлений недоліків і потребує вдосконалення. Проведені дослідження вітчизняного механізму оподаткування доходів фізичних осіб дають змогу стверджувати, що в нині чинному варіанті він не відповідає ні конституційним ознаками соціальної держави, ні принципам соціальної справедливості. Тому, з соціально-економічної точки зору, стимулюючий ефект 
від запровадження уніфікованої шкали оподаткування доходів для всіх верств фізичних осіб, без врахування розміру самих доходів, призводить до того, що високооплачувані платники мають преференцію в оподаткуванні, а сам ефект зниження податків вельми обмежений. Таким чином, зниження податкового навантаження відобразилося лише відносно платників з високим рівнем доходів, не вплинувши в цілому на основну масу платників податку. А в цілому такий підхід не відповідає постулатам соціальної справедливості й унеможливлює ефективну соціальну спрямованість оподаткування, що призводить до посиленого розшарування суспільства та ухилення від оподаткування.

В Україні, незважаючи на законодавчо встановлене оподаткування доходів фізичних осіб i прописаний принцип соціальної справедливості, наразі відсутня цілісна концепція формування соціальної спрямованості даного податку. Хоча, відповідно до статті 46 Конституції України, «...громадяни мають право на соціальний захист, що включає право на забезпечення їм гідного життя, вільного розвитку людини, послідовного підвищення рівня життя населення та зниження соціальної нерівності, забезпечення загальної доступності основних соціальних благ, перш за все, якісної освіти, медичного і соціального обслуговування».

У більшості країн світу дохідна частина бюджету значною мірою залежить від надходжень прибуткового податку (податку на доходи фізичних осіб), а тому йому надається особливе значення у вирішенні соціальних проблем суспільства. Адже соціальна функція податків і соціальна спрямованість механізму оподаткування доходів фізичних осіб, спрямовані на перерозподіл суспільного блага, створюють стимули та ресурси для досягнення високих життєвих стандартів на основі соціальної рівності та справедливості. У 
той же час, відповідно до чинного податкового законодавства, у вітчизняному механізмі оподаткування доходів фізичних осіб не врахована основна особливість цього податку - розмір отриманих доходів кожною окремо взятою особою та іï платоспроможність. Хоча, як зазначалося вище, базисом оподаткування доходів фізичних осіб повинні слугувати, насамперед, соціальна функція і соціальна спрямованість, в основу яких покладається соціальна справедливість не тільки відносно індивіда, але й сім’ї, як єдиного господарюючого суб’ єкту. Адже ще А. Сміт дотримувався такої тези, що «...справедливість є однією 3 найбільш важливих принципів оподаткування».

Наразі пересічний громадянин України - платник податків не бажає добровільно виконувати свої податкові зобов'язання. Причиною цього $є$ відсутність чітко вираженої залежності між сплаченими податками та зворотним потоком державних послуг, що їх отримують платники. У світовій практиці виділяють три моделі взаємовідносин держави та платників податків:

- домінування держави у взаємовідносинах «держава платники податків». У цих взаємовідносинах платники здебільшого наділені обов'язками, а держава - правами. Платники податків у такій моделі розглядаються як постачальники фінансових ресурсів. Оскільки їхні права обмежені, то вони не зацікавлені в добровільному виконанні своїх податкових зобов'язань, тому рівень ухиляння від оподаткування є високим. Держава зі свого боку збільшує адміністративний тиск, застосовуючи дедалі жорсткіші засоби контролю. У результаті збільшується державний контрольний апарат і зростає рівень тіньової економіки. Така модель притаманна авторитарним державам i, безумовно, не може застосовуватись у демократичних країнах; 
- домінування платника у взаємовідносинах «держава платники податків». Така модель притаманна слабким державам iз низькоефективним державним апаратом. Унаслідок безконтрольних дій платників рівень ухилення від оподаткування, як і в попередній моделі, зростає. Таким чином, зменшується обсяг податкових надходжень до державного бюджету й викривляються умови конкурентного середовища, оскільки платники податків, що ухиляються від оподаткування, отримують додаткові фінансові ресурси для подальшого їх інвестування у свій бізнес. Модель домінування платника не може бути ефективною, оскільки рано чи пізно їі наслідком стане криза державних фінансів і посилення державного контролю аж до домінування держави над платниками;

- модель взаємних зобов'язань. Цю модель обирають демократичні країни та країни 3 перехідною економікою. Усі суб'єкти податкових відносин є рівноправними, а діяльність кожного 3 них $є$ підконтрольною та підзвітною. I держава в особі фіскальних органів, і платники зобов'язані дотримуватися податкового законодавства та наділені однаковими гарантіями щодо дотримання й захисту своїх законних прав. Платник розглядається вже не як об’ єкт контролю, а як рівний партнер, який сплачує платежі податкового характеру за отримання належних послуг і гарантій із боку держави.

Отже, удосконалення системи адміністрування податків має розпочинатися 3 налагодження партнерських взаємовідносин між платниками та податковими органами, що базується на якісно новому розумінні місця людини в державі й у податковому адмініструванні, на повазі до її прав та інтересів. У такому разі сплата громадянами платежів податкового характеру буде добровільною, а не примусовою. 
Ще одним спірним моментом у вітчизняному оподаткуванні доходів фізичних осіб є застосування єдиної ставки податку до різних за обсягом доходів. Вирішити цю проблему можливо тільки при впровадженні системи прогресивного оподаткування, оскільки величина відрахувань за сучасного методичного підходу обчислення досліджуваного податку економічно не обгрунтована та не має істотного стимулюючого значення для платника податків, а відтак не забезпечує належну диференціацію споживання.

Зарубіжний досвід оподаткування доходів фізичних осіб свідчить про позитивні тенденції застосування прогресивного оподаткування, за допомогою якого можливо здійснити перерозподіл благ, спрямувати ресурси на реалізацію програми соціальної підтримки населення, оскільки за рахунок підвищених ставок оподаткування доходів, особливо в частині надприбутків, забезпечується соціальна програма держави. Тому вважаємо, що, 3 огляду на специфіку української економіки, необхідно повернутися до застосування прогресивного механізму оподаткування доходів фізичних осіб, завдяки якому буде знято навантаження з соціально незабезпечених верств населення. Як доказ - низька частка податків 3 оплати праці у ВВП України в порівнянні з показниками окремих європейських держав.

Загалом вітчизняна система справляння та адміністрування ПДФО характеризується як недосконала, а основними проблемами $€$ :

- недотримання принципу соціальної справедливості під час оподаткування доходів громадян;

- надмірна орієнтованість спочатку лише на фіскальну складову з одночасним забуванням про податок як один з ключових методів перерозподілу національного доходу; 
- нерівномірне навантаження на доходи населення, в результаті чого значна частина податкових надходжень до бюджету відбувається за рахунок доходів осіб з низьким рівнем доходу;

- функціонування тіньового сектору економіки, де переважає заробітна плата в конвертах;

- високий рівень податкового навантаження.

Також, проаналізувавши діючу систему оподаткування фізичних осіб, які проводять незалежну професійну діяльність в Україні, можемо стверджувати, що вона має ряд недоліків. Першою та найбільш вагомою проблемою в оподаткуванні суб'єктів незалежної професійної діяльності, на наше переконання, є значне податкове навантаження, що сприяє лише уникненню платниками податку оподаткування та створенню незаконних схем.

Перш за все, це виражається в сплаті єдиного соціального внеску. Так, згідно з змінами з 1 січня 2017 року, не зважаючи на те, чи $є$ в особи доходи в певному місяці чи вони менші мінімального розміру заробітної плати, особа повинна сплатити мінімальний розмір внеску, тобто 704 грн. Також це стосується податкового навантаження загалом. Оскільки особи сплачують 18\% податку на доходи фізичних осіб, 20\% єдиного соціального внеску та 1,5\% військового збору. Таким чином, самозайнята особа сплачує майже половину свого доходу як податки, що підштовхує людей уникати оподаткування різними способами, в тому числі й не законними.

Військовий збір - податок, який було введено в 2014 році для фінансування Збройних сил України. Цим податком обкладаються доходи фізичних осіб на території України. Ставка військового збору складає 1,5\% від нарахованої заробітної плати.

Військовий збір було запроваджено як тимчасовий податок (спочатку до кінця 2014 року) для фінансування Збройних сил 
України під час проведення АТО у зв'язку з російською агресією. Наразі його тимчасовий статус формально, як і було започатковано, зберігається, але тепер термін його дії продовжено до закінчення реформування ЗСУ. Але, судячи з темпів реформ - його скасування найближчим часом очікувати не доводиться.

Наступною проблемою є можливість застосування єдиного податку при оподаткуванні самозайнятих осіб, що породжувало багато суперечностей. Вирішальною в даній дискусії стала Постанова Вищого адміністративного суду України від 21 січня 2016 р. у справі № 808/7758/13-а в якій йдеться, що якщо адвокат зареєстрований як суб’єкт незалежної професійної діяльності - фізична особа-підприємець і є платником єдиного податку, то тоді адвокат має право платити виключно єдиний податок, як i інші суб'єкти незалежної професійної діяльності - фізичні особипідприємці, залежно від групи до якої його відносить Податковий кодекс України.

В своєму рішенні Вищий адміністративний суд посилається на те, що згідно з Законом України «Про адвокатуру та адвокатську діяльність» не існує заборони для здійснення адвокатом підприємницької діяльності. До того ж передбачено, що адвокат, який здійснює адвокатську діяльність індивідуально, є самозайнятою особою. В підпункті 14.1.226 пункту 14.1 статті 14 ПК України зазначено, що самозайнятою особою є платник податку, який $є$ фізичною особою-підприємцем або провадить незалежну професійну діяльність за умови, що така особа не є працівником в межах такої підприємницької чи незалежної професійної діяльності.

До того ж пунктом 291.5 статті 291 Податкового кодексу, де передбачений перелік осіб, що не можуть бути платниками єдиного податку, де самозайняті особи, суб’єкти незалежної професійної 
діяльності не зазначені.

Поряд 3 тим, що законодавство щодо оподаткування самозайнятих осіб-суб'єктів незалежної професійної діяльності здавалось є доволі деталізованим, все ж виникає багато дискусій щодо того чи іншого аспекту. Контролюючий орган намагається трактувати норми закону на свою користь і стягувати з платників податків, що мають значний податковий тягар, додаткові кошти за порушення тих чи інших норм. Саме через це в Україні сформувалась певна судова практика, що дозволяє платнику податку захищати свої права та інтереси.

Перш за все, це стосується питання визначення бази оподаткування. Як вже згадувалось базою оподаткування є чистий річний оподатковуваний дохід, тобто різниця між доходом i документально підтвердженими витратами, необхідними для провадження певного виду незалежної професійної діяльності. А саме визначення переліку витрат, що виключаються з доходу. Існує узагальнююча консультація щодо цього питання 3 орієнтовним переліком витрат, але контролюючий орган трактує цей перелік як виключний, притягуючи до відповідальності платників податків, що включають до свого переліку відмінні від перелічених витрати, через що і виникають спори.

Вирішуючи такі питання, потрібно зважати на пункт 4.1.4. статті 4 Податкового кодексу, що передбачає презумпцію правомірності рішень платника податку в разі, якщо норма закону чи іншого нормативно-правового акту, виданого на підставі закону, або якщо норми різних законів чи різних нормативно-правових актів припускають неоднозначне (множинне) трактування прав та обов'язків платників податків або контролюючих органів, внаслідок чого є можливість прийняти рішення на користь як платника податків, 
так і контролюючого органу. Суди при вирішенні даних питань керувались тим, що вказана консультація має рекомендаційний характер, і наведений у ній перелік не є вичерпним, що свідчить про можливе віднесення до необхідних витрат незалежної професійної діяльності й інших витрат. Також, аналізуючи рішення першої та апеляційної інстанції, можемо побачити, що суд дійшов висновку, що в кожному окремому випадку слід аналізувати здійснені витрати за критеріями можливості використання придбаних товарів (робіт, послуг) у незалежній професійній діяльності, ділової мети їх придбання, впливу цих витрат на отримання доходу, й за умови відповідності таким критеріям придбані товари (роботи, послуги) й здійснені витрати слід вважати такими, що необхідні для провадження незалежної професійної діяльності.

Так, наприклад, суди визнавали правомірним включення до переліку витрат:

- платежі за договором іпотеки на придбання квартири, яка використовується для здійснення незалежної професійної діяльності;

- комунальні платежі та придбання паперу;

- витрати на оплату рекламних послуг та послуг iз опублікування статей, витрати на забезпечення функціонування офісу та офісної техніки (Ухвала Львівського апеляційного адміністративного суду від 08.09.2016 року);

- витрати на охорону приміщення, придбання товарноматеріальних цінностей для утримання приміщення в належному стані.

Таким чином, зважаючи на наведені вище проблеми, можемо зробити висновок, що податкове законодавство України потребує змін для їх врегулювання. Українське законодавство досить 
формалізоване та все ж не досконале. Частина суперечностей врегульовані судовою практикою. Наприклад, можливість застосування єдиного податку в оподаткуванні адвокатів, нотаріусів та інших осіб, що підпадають під категорію осіб, що займаються незалежною професійною діяльністю.

Складність податкового законодавства та небажання деяких платників вчасно і повністю сплачувати податки спричиняє те, що більшість осіб, які здійснюють незалежну професійну діяльність, приховують свою діяльність і, відповідно, 3 метою ухилення від оподаткування, доходи. На нашу думку, ухилення від сплати податків є домінуючим сегментом тіньової економіки, при цьому основними причинами, що зумовлюють існування явища ухилення від оподаткування, є нестабільність і недосконалість податкового законодавства та відсутність податкової свідомості у платників податків.

Отже, аналіз проблем механізму справляння та адміністрування ПДФО засвідчив, що, незважаючи на те, що система прямого оподаткування забезпечує сталі надходження значної частини доходів бюджетів різних рівнів, сучасний механізм нарахування й сплати ПДФО не позбавлений значних недоліків, основними з яких є пропорційні ставки цього податку, відсутність порядку оподаткування доходів сім’ї загалом, а не доходів кожного громадянина окремо, недосконалий порядок розподілу мобілізованих сум податку між бюджетами.

Проведений аналіз показує, що ПДФО в Україні може бути представлене одним податком або ж кількома, нараховуватися за прогресивною шкалою, належати до місцевих чи загальнодержавних податків у пропорції стосовно рівня податкоспроможності регіону та спрямовуватись до одного чи кількох суб'єктів оподаткування, що 
визначатиме його регуляторну ефективність. В Україні, на відміну від інших країн світу, найважливішими базами оподаткування ПДФО залишається заробітна плата та проценти, а багаті громадяни залишаються «недоторканною кастою».

У світовій практиці оподаткування доходів фізичних осіб розглядається як важливе джерело надходжень до бюджету та інструмент перерозподілу доходів між високозабезпеченими та малозабезпеченими категоріями населення. Існують різні підходи до оподаткування податком на доходи фізичних осіб - пропорційний та прогресивний. Також виокремлюють дві системи оподаткування: PAYE (pay as you earn) - система сплати податку у джерела доходу та PAYG (pay as you go) - система сплати податку за допомогою декларацій. За системою оподаткування РАҮЕ ключовим є те, що хоча особа не виступає платником податку у контексті відповідальності (податковий агент-роботодавець), проте цей податок утримується із їі заробітної плати. Ця система має переваги у контексті рівномірності податкових надходжень протягом календарного періоду та всеохоплюваності, порівняно з податковим декларуванням, оскільки прибутковий податок (PIT) сплачують майже всі фізичні особи, що отримують дохід у вигляді заробітної плати.

Оподаткування доходів фізичних осіб у зарубіжних країнах має свої особливості. Одні і ті самі доходи в різних країнах можуть як підлягати оподаткуванню, так і звільнятися від нього. Двома основними джерелами доходів, що підлягають оподаткуванню у більшості країн світу, є доходи від заробітної плати та доходи від капіталу (пасивні доходи). Загалом у країнах ЄС оподатковується близько 16 видів доходів фізичних осіб (рис. 5.7). Сьогодні спостерігаються тенденції лібералізації оподаткування доходів від капіталу. 


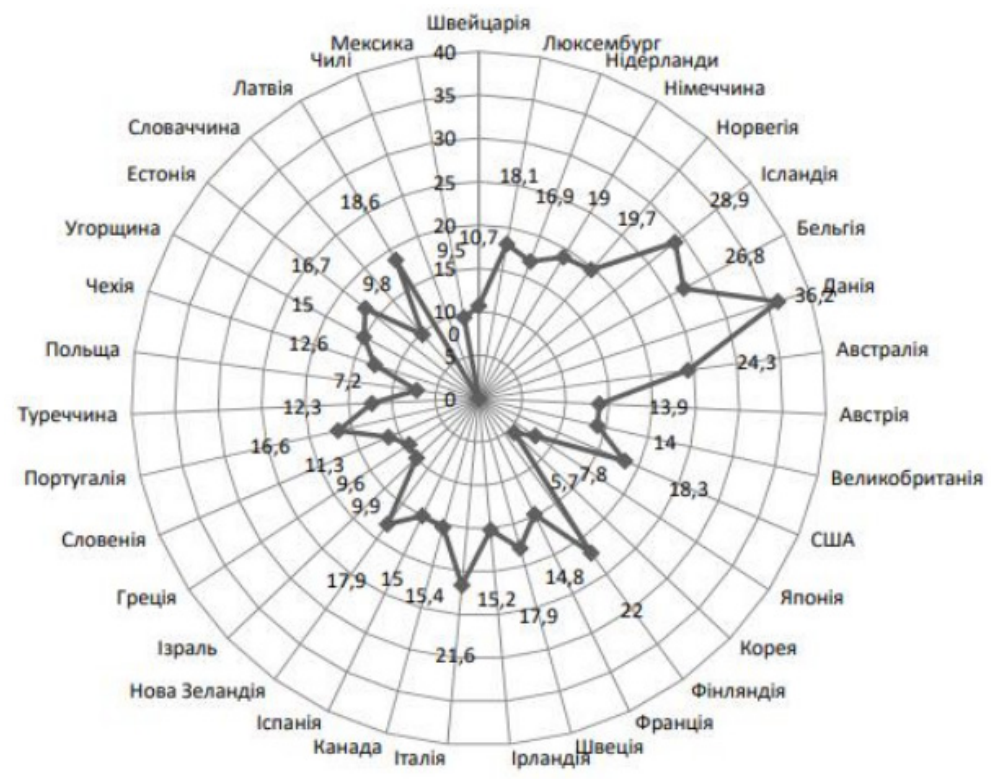

\section{Рис. 5.7. Середня величина PIT, що утримусться із заробітних плат у державах ОЕСР, \%}

В країнах-членах ОЕСР визначено різний рівень податкового навантаження на заробітну плату осіб, які працюють. Держави, що гарантують громадянам високий рівень соціальної безпеки, встановлюють значно вищі ставки податку на доходи фізичних осіб, за рахунок чого і забезпечуються високі соціальні стандарти.

Найбільше навантаження на заробітну плату осіб, які працюють, спостерігається у таких державах, як: Данія $(36,2 \%)$, Ісландія (28,9\%), Бельгія (26,8\%), Австралія (24,3\%), Італія (21,6\%).

Низький рівень податкового навантаження на заробітну плату в Кореї (5,7\%), Польщі (7,2\%), Японії (7,8\%). Разом із цим, Чилі єдина країна серед держав ОЕСР, у якій податок на доходи фізичних осіб працівники не сплачують.

У Європейському Союзі та країнах-членах ОЕСР для 
оподаткування доходів громадян застосовується PIT (personal income tax) - прибутковий податок для фізичних осіб. Цей податок як складова системи оподаткування доходів фізичних осіб є вагомим джерелом надходження коштів до бюджетів різних рівнів.

Отже, спираючись на іноземний досвід, можна «вмонтувати» певні світові здобутки в українську систему оподаткування на основі раціонального поєднання найкращих передових методів та елементів податкових систем зарубіжних країн, що дало б поштовх до посилення соціальної складової системи оподаткування.

Зважаючи на недоліки вітчизняної системи оподаткування доходів громадян, вважаємо, що доцільними будуть такі дії з боку Уряду та Парламенту в напрямі вдосконалення механізму справляння та адміністрування ПДФО:

- необхідність розширення бази оподаткування ПДФО (можливість залучення до оподаткування всіх доходів, які виплачують із державних цільових фондів, що одержуються як компенсація, відшкодування певних витрат, доходи від інтелектуальної власності;

- запровадження прогресивної шкали оподаткування доходів;

- вдосконалення пільгової політики щодо ПДФО (впровадження неоподаткованого мінімуму на рівні мінімальної заробітної плати, упорядкування ПСП соціально незахищеним громадянам та громадянам, що мають заслуги перед державою;

- розроблення механізму стягнення податків з інших доходів громадян (податок на розкіш);

- вжиття засобів щодо підвищення ефективності податкового нагляду (контролю), що сприятиме подоланню зловживань та ухиленню від сплати податків;

- легалізація доходів громадян, одержаних від «тіньової» 
економічної діяльності;

- нарощування податкових надходжень до Зведеного бюджету шляхом залучення таких резервів, як зростання доходів фізичних осіб, створення робочих місць, заходи щодо збільшення кількості працездатного населення та збільшення інвестицій в економіку;

- застосування комбінацій щодо використання ПДФО. Усі види доходів повинні мати особистий механізм оподаткування, який справді враховує особливості їх отримання, вагомість для платника та трудомісткість адміністрування.

Реалізація на практиці цих заходів стане запорукою підвищення довіри до державних інституцій, відновлення принципу справедливості, сприятиме виведенню з тіні доходів, зменшенню податкового тягаря й конфліктності між платниками податків і контролюючими органами та покращенню податкової дисципліни.

\section{Список використаних джерел:}

1. Податковий кодекс України: Відомості Верховної Ради Украӥни. 2011. №13-14. № 15-16. № 17. Ст. 112.

2. Конвенція про основні цілі та норми соціальної політики №117: ратифіковано Законом №692-VIII від 16.09.2015. Верховна Рада України. URL: http://zakon5.rada.gov.ua/laws/show/993_016.

3. Офіційний портал ДФС України. URL: http://sfs.gov.ua/ diyalnist-/pokazniki-roboti/nadhodjennya-podatkiv-i-zboriv--obovyaz/ nadhodjennya-podatkiv-i-zboriv/.

4. Податки і збори з населення в СРСР. Фінанси. 1968. 183 с.

5. Гайдай B.I. Механізми державного регулювання ПДФО в умовах децентралізації влади в України. Інвестиції: практика та досвід. 2019. №17. С.69-74.

6. Дутова Н.В. Оподаткування доходів фізичних осіб в України: проблеми та вдосконалення на базі досвіду зарубіжних 
країн. Економіка і організація управління. 2019. Вип. 1. С. 43-52.

7. Ільяшенко В. Удосконалення системи адміністрування податкових платежів до державного бюджету. Ефективна економіка. URL: http://www.economy.nayka.com.ua/?op=1\&z=1953.

8. Легкоступ I.I. Податкові системи в умовах глобалізації: проблеми взаємодії та перспективи розвитку. Бізнес Інформ 2014. №14. C. 259-263.

9. Пешко К. Податки в Україні платити так легко, як і у Німеччині? (дослідження). URL: https:/glavcom.ua/ economics/ finances/podatki-v-ukrajini-platiti-tak-legkoyak-i-u-nimechchinidoslidzhennya--453396.html.

10. Развитие самозанятости в странах Европейского Союза и CШA. URL: http://www.vneshmarket.ru/content/documentA4F920722395-4116-96E5-EE76169118c7. 